DOI: https://doi.org/10.3126/njdrs.v18i01.41950

\title{
Role of Mother's Group on Women Empowerment: A Case Study of Godawari Municipality, Lalitpur
}

\author{
Susmita Gautam \\ Lecturer at Trichandra Multiple Campus \\ Department of Rural Development, Tribhuvan University, Nepal \\ Email:susmita.gautam@trc.tu.edu.np
}

\begin{abstract}
Mother's Group is one of the basic groups for women empowerment. It has been functioning for women's empowerment and social development. Mothers group has managed many skill development programs, income generating programs, literacy programs etc which helped them to make independent. Mother's group, self-help groups ( $\mathrm{SHG}$ ) and community-based organizations $(\mathrm{CBO})$ play a vital role towards women empowerment by providing vocational trainings, training for self-employment, protection for women and self-awareness programs. Thus, they are mainly concerned with the upliftment of the women in the society. Empowerment of women has been a topic discussed at length in recent times and many strategies have been implemented to address enhance women's condition. This paper seeks to explore some measure that should be adopted in order to position rural women as equal players in entrepreneurship and economic development. This paper discusses upon the empowerment of rural women by means of self-help group or mother's group and the advantages of such groups among the rural women.
\end{abstract}

Key words: Self-help group, women empowerment, economic development, gender equality

\section{Introduction}

The beginning of the concept of empowerment can be traced back to the works of Paulo Freire, a Brazilian scholar, who championed the concept of the "the Pedagogy of the Oppressed" (Freire, 1974). Empowerment is an interactive process through which people experience personal and social change, enabling them to take action to achieve influence over the organization and institutions which affect their lives and the communities in which they live. Social development may be seen as a process of ushering in a new order of existence. The quality of life and the quality of social relations which exist would indicate the level of the order of existence. The activities of Mother's Group are implemented for community development.

Nepalese women are deprived and discriminated in every nook and corners and individual family, society and national level. Women are subordinated and oppressed. They have less access to productive assets like land, property and credit. They have been deprived of modern education, health, training, household resources and technology and have less career building opportunities than males because of gender stereotyping at school and the socializing process. Women in Nepal still have less access to decision-making level because they are less educated. Nearly $51 \%$ is occupied by the population of women, where $42.5 \%$ female are literate in comparison to $65.1 \%$ of the male out of the total population of Nepal (CBS, 2011).

Mother's group is perhaps one of the most universalized traditional voluntary organizations in Nepal. It first started with the Gurung of Western Nepal. As most of the Gurung men used to join in the British Army, and more recently, in Indian Army for the last two decades. Gurung women formed mother's group to sing, dance and organize cultural activities in the evening. One of the most interesting activities they perform is to welcome returnee Lahures and guest visitors. The Lahures (returnee British or Indian army men) and guest visitors donate money to the Mother's Group. These collected money is used 
to build trails, temples etc. Mother's group, as a program was first introduced as mother's club during International Women's Year in 1975 with the initiation of social services, National Co-ordination council (Pokharel, 1999). The objective of the program was to enhance mother's social and economic status. The activities of such mother's club consisted of family planning, health, education, and social and economic development of mothers. The concept of mother's club changed into mother's group and got popularity as government and other non-governmental organizations adopted the concept widely and began to form mother's group for both service delivery as well as women's empowerment.

Empowerment is a process of awareness and capacity building to grater decision making power and control resulting in transformative action. In fact, empowerment as a theme arose out of a failure of "Women in Development" (WID) programs, notably the equity approach all of which failed to question the interrelationship between power and development. Empowerment approach developed out of dissatisfaction with the original WID as equity approach, because of its perceived co-option into the antipoverty an efficiency approach (Moser, 1993).

Nepalese women need social and economic support from the governmental and nongovernmental sectors to achieve women's empowerment. Acharya (1997), in her book "Gender Equality and Empowerment", viewed the process of empowerment in the context of Nepal as:

- Increasing women's access to economic opportunities and resources (employment, credit, wealth, technology and non-economic resources such as education, knowledge and health)

- Increasing women's political power through women's organizations, solidarity and collective actions (political will and ability to bring changes in women's legal status to direct resources to women give the access to positions of power).

Women empowerment means "the idea that giving women power over their economic, social and reproductive choices which will raise economic status, promote overall development". This can be view as a continuum of components including:

- Awareness building about women's situation for rights and discrimination, and opportunities as a set towards gender equality. Collective awareness building provides a sense of group identity and power of working as a group.

- Capacity building and skill development

- Participation and greater control over decision making power in house hold activities community and society.

\section{Objectives}

- To explore the role of mother's group on women empowerment.

- To study the socio-economic dimension of women and mother's group.

\section{Materials and Methods}

This study employs the exploratory research design to explore the prominent role of self-help groups (mother's group). 100 women out of 300 women (i.e members of Srijanshil Mahila Samuha, Chapagau of Godawari municipality) were selected as respondents through purposive sampling method. Both primary and secondary data were used. The primary data were collected through in-depth face-to-face structured interview and observations whereas the secondary data were collected reviewing literature through search engines. The collected data has been checked, coded, categorized, organized, and converted into data sheet. Data was analyzed descriptively through percentage, frequencies, and average mean value.

\section{Results and Discussions: Social Demography}

Mother's Groups empower women to participate in the community and in various activity and help the members to handle the issue concerning their socio-economic, political wellbeing and mold women as a responsible citizen with social and economic status. It enables women to develop the habit of thriftiness and small saving inculcated with the sense of belongingness and discipline among themselves. It motivates the women to initiative to educate their own members with great enthusiasm. Women Self-help group tries to 
uplift the women who are mostly marginalized in the social structure by instilling self-confidence and selfreliance besides in decision making. The age structure, educational status, occupational status, objectives of involvement, and purpose of involvement has been included under Srijanshil Mahila Samuha, Chapagaun of Godawari municipality.

Age Structure. The majority of the respondents' women are between 25 to 50 years and no one is unmarried. The majority of women are between 30 to 40 years (i.e., 37 percent) and 27 percent are 20 to 30 years, 23 percent are 40 to 50 years and remaining 13 percent are above 50 years old. This structure shows that the mother's groups have focused their activities towards the active age women group who are involved in the productive sectors.

Educational Status. Education is the eye of people and plays an important role in human life without which people cannot do anything. This study shows that 25 percent women involved in this mother's group are illiterate and 75 percent are literate. However, 18 percent women are under SLC, 50 percent women have passed only SLC, five percent women have passed intermediate level and only two percent women have passed bachelor's degree. It can be concluded that MG have provided opportunities to the women especially for illiterate and poor educational background.

Occupational Status. Nepal is an agricultural country. Almost 76 percent of the total populations of Nepal are involved in agriculture and the percentage of women involved in agriculture is more than the men (NLSS 2012). Most of the women in Chapagaun are involved in agriculture (70 percent). Similarly, 21 percent are in retail trade and rests are in tailoring and teaching 4 percent each and beautician occupies 1 percent.

Objectives of Involvement in MFIs. The women of Chapagaun have been involved in different mother's group (self-help group) with various objectives. Some women focus on saving while others have easy loan objective or both. Most of the respondents have both saving and easy loan objective behind the involvement in the group. The study shows that 44 percent respondents have saving and easy loan objective, 30 percent have only saving objective, 24 percent have only easy loan objective and two percent have another objective (social objective).

Saving Pattern of Women. Women involved in mother's group for saving, easy loan and other objectives. Women regularly save small amount of money on monthly and fortnightly basis. The study shows that the highest number of periodical regular saving made by women ranging of Rs. 100 to Rs. 200 is 37 percent whereas30 percent women regularly save Rs. 200 to Rs. 300. Similarly, nine percent respondents' women have regular saving less than Rs. 100, 12 percent saves between Rs. 300 to Rs. 400, seven percent saves between Rs. 400 to Rs. 500 and five percent have regular saving more than Rs. 500.

\section{Mother's Group and Social Dimension}

The level of awareness, social relationship and leadership capacity has been included under the social dimension.

Level of Awareness. Majority of women responded that such groups have helped them to learn different new things and to increase their level of awareness. In total, 59 percent women expressed that their level of awareness has been increased and 41 percent have no effect.

Social Relationship. The Srijanshil Mahila Smuha organize regular meeting of its unit's members. Since all members should attend the meeting compulsory, so it helps to increase the social relationship of the participants. The majority of women have highly positive responses regarding the social relationship that has been enhanced by group intervention.

Leadership Capacity. Majority of women reported that there is change in leadership capacity after participation in the group's activities. 50 percent women have positive impact on leadership capacity. Similarly, 45 percent women have expressed that their leadership capacity have been changed due to involvement in Samuha. In overall, only 25 percent of women reported that their leadership capacity has not been changed after participating in the activities organized by Samuha. 


\section{Mother's Group and Economic Dimension}

The economic transformation includes income level, living standard, and expansion of small business. Majority of women have positive response towards the change in income level. In aggregate, 46 percent of women have positive impact regarding the change of income level and 54 percent have not felt such changes even after active involvement in mother's group programs.

Living Standard. The socio-economic status of women can be judged on the basis of various aspects. The researcher has taken responses from the respondents regarding the change in living standard, income level, expansions of business, level of awareness, social relationship and leadership capacity of women after involvement in mother's groups. In total 26 percent women has expressed positive response toward their living standard and 74 percent women answered that their living standard has not changed even after participation in programs led by mother's group.

Expansion of Business. The majority of women have positive response towards the expansion of business whereas others have no impact on expansion of business. In overall, programs have helped 39 percent women to expandtheirbusinessandrest61 percent have no effect.

\section{Conclusion}

Empowerment of women, being a feminist ideology, wish to empower other deprived women. These empowered women by associating with any self-help organization or mother's group whose mission is closely related to their ideology, will be able to realize their beliefs, and this gives them a high level of satisfaction and accomplishment. Earnings and independence of women along with social security must be the primary mission of these women self-help groups. Empowerment, as defined for Nepalese rural women, is a complex set of condition, being knowledge, skilled, confident, having the ability and willingness to share time and skills, able to speak in public, earn money and generally being to stand on one's own feet. Mother's group have played a vital role in the field of women's empowerment, social activities and social awareness in terms of primary health care, childcare, nutrition, sanitation, family planning including reproductive health, changing traditional concepts about childbirth and childcare, child education and women's education, and increment of self-motivated participation in different developmental activities (physical and social infrastructure). If such programs can be made available to those who are starting self-help groups or mother's group, or who are in the process of doing so, they may be able to increase the chances of success to those entrepreneurs. Thus, the role of mother's group towards empowerment of women is very crucial in the Nepalese scenario.

\section{References}

Acharya, M. (1978). "Statistical profile of Nepalese women: A critical review". The Status of Women in Nepal.

Acharya, S., Yoshino, E., Jimba, M. \&Wakai, S. (2007). Empowering Rural Women through a

Community Development Approach in Nepal.Community Development Journal, 42(1), 34 - 46.

Central Bureau of Statistics [CBS]. (2001). Annual report. National Planning Commission and CBS Publication.

Central Bureau of Statistics [CBS]. (2011). "Population Monograph of Nepal". National Planning Commission. Government of Nepal.

Freir, P. (1974). "The Pedagogy of Oppressed”, Brazil.

Ministry of Finance [MoF]. (2019). Economic Survey, 2018/19. Government of Nepal.

Ministry of Finance [MoF]. (2021). Economic Survey, 2020/21. Government of Nepal.

Moser, S. (1993). "Gender Planning and Development: Theory, Practice and Training”. Routledge.

Nepal Living Standard Survey [NLSS]. (2011). Statistical Report Volume Two, Central Bearau of

Pokharel, Y. (1999). "Evolution of Traditional/Indigenous Institutions and Their Relevance in Development Co-operation”. Sajha Prakashan. 